\title{
Reflections of an Ontario Student Teacher in Scotland: Cultural Language and Cross-Cultural Classroom Management
}

\author{
Alexandra Gayowsky, OCT \\ University of Windsor
}

\begin{abstract}
A new teacher in her initial teacher education (ITE) program is focused on curriculum content, classroom management and pedagogy, and this perspective does not change despite a variation in the cultural context (Hassaram, Robertson, \& Garcia, 2019). "Reflections of an Ontario Student Teacher in Scotland" is a narrative of raw, qualitative reflexive data composed during a one-week period of ITE practice teaching placement in Northern Scotland (Clarà, Mauri, Colomina, \& Onrubia, 2019). The English teacher-narrator identifies the language differences, comparative abilities in writing, and those one-on-one connections between student teacher and pupils that allow for a rewarding reciprocal learning experience in first year classroom management and teaching.
\end{abstract}

\section{Day One}

The headmistress gave us a tour of the school, which took over two hours. This might be the most beautiful school I have ever seen. Outside, in the front courtyard, stands an archaic bell tower with red and brown brick and spotted patchwork giving insight to its long lifespan. The roof is made of wood shingles and beneath boasts a large clock with Roman numerals. The school itself is quite different. A modern and open-concept hall welcomed us. Rows of skylights highlighted, what I assumed to be, an art installation consisting of several multi-coloured wooden beams hanging vertically from the ceiling. There are separate wings for subjects; each have their own teaching lounge. Finding ourselves in the English wing was exciting, as designated spaces for disciplines are not something I experienced in primary or secondary schools in Windsor. The classrooms here are lined with bookshelves (and filled with actual books!), whiteboards, windows, literary posters, and bulletin boards. In Windsor, I found that individual teachers often have to supply their own literature collections, aside from the standard literacy curriculum textbooks. 
The third-year secondary (S3, or age 14) students were preparing for their national examinations so they did not have much classroom work today. This explained the rows upon rows of neatly lined desks in the auditorium.

The S1 students were talkative and excited. They studied the short story "The Pedestrian" by Ray Bradbury, and Miss Macleod conducted a guided reading with them. She read the story aloud with the students, provided context, and prompted students to engage in meaningful conversations. I was quite fond of utilizing this instructional approach during my teaching practice in Windsor and seeing it here felt familiar and comforting.

One of the students said I have a nice accent.

I responded, "Thank you. So do you!"

Smiled and surprised, she asked, "Oh! Do I have an accent too?"

They use "Text for Scotland" which seems to be their version of the Ontario Nelson curriculum textbooks. (The students here do not seem to like it much either.)

S5 students seem very quiet. They are reading "Romeo \& Juliet" and "The Great Gatsby" right now. Lecture-based classes seem to be the norm for this level, very much resembling a traditional post-secondary English literature classroom. From my experience in Ontario, an equivalent Grade 11 class would include more activity-based learning and media-based resources.

I overheard students using the following common diction: rubbish (garbage and/or nonsense), fortnight (two weeks), and bird (girl).

\section{Day Two}

I scribed the third-year secondary (S3) English examination for a student with special needs. He wrote about his favourite show, "Primeval." There is a special series of the show that takes place in Canada and he seemed rather impressed to tell me that information. When it was revealed that he had reached 700 words, he straightened his back and smiled, proudly. He said his record was 800 words.

I taught S1 students about Canada today. Cory took notes. Based on his quickness to retrieve a paper and pencil, it appeared that Cory often received special tasks like this. Afterwards, we went to the library (there is a library!) and took out books on Canada. The students had a lot of questions including:

"Are there gangs?"

"Do you have horses?", and,

"What is the most popular restaurant?"

Many said they wanted to try poutine. Considering that a local restaurant asked if we wanted mayonnaise, shredded cheese, and ketchup on our fries, I was not surprised that poutine intrigues them. I administered a quiz and overall, they did quite well, even with the spelling. Many 
couldn't remember Ottawa as Canada's capital, but then I didn't realize that Edinburgh was the capital of Scotland either.

The students in S1 were very certain that Glasgow was the most dangerous city in the world. I asked Cory if he had ever been to Glasgow and he said that he had been left there as a baby for two years until the social worker came and brought him here.

Today, I also discovered A4 paper! A4 paper is 8.5 X 11.5 inches, just a half inch longer than the normal size letter paper we use daily for photocopying and letters. Lined A4 paper has two holes rather than three.

There are many plastic containers around the classroom that are used for communal supplies. I noticed I received many blank stares and crinkled brows when I mentioned these 'bins' and thought it was odd since the containers seemed like such common practice in their classroom. Finally, one of the students told me that they only use the bin for rubbish, and I realized that the whole day they thought I was telling them to go to the garbage for supplies.

\section{Day Three}

In my S4 class today, I used football as a topic, to great effect, for discussion regarding developing effective arguments; for example: Should Rangers and Celtic be allowed to join the English Premiere League?

In my S3 class, now that they were done their national examinations, I taught the poem "This is a Photograph of Me" by Margaret Atwood. While trying to engage students with topics they were familiar with, I was also trying to consciously choose Canadian texts to expose them to. When we discussed unfamiliar words in the poem, they revealed that they did not know what an Evergreen tree was, and they were quite thrilled to learn that we have of an abundance of "Christmas trees" growing all over Canada. They were very attentive today and I am finding these students to be quite lovely in general. They are not much different (other than the obvious things) than the children in Canada. When we analyzed the Atwood poem, I gave them the option of writing a description of their initial perception or to sketch a drawing. Since this was a lower level class, there were some students that had severe difficulties with writing. My hope was to allow these students an equal opportunity to participate in the activity and express their ideas. I noticed that several of the other students also chose to draw and it ended up being quite fun. They were very intrigued by the "dead" figure in the poem.

I am adapting to the variety of different levels and grades throughout each day's schedule, ranging from SI to S5 (eleven to sixteen years old). I am also adapting to the expectations the teachers here have of their students. Student expectations seem quite high, and I wonder if the inclusion of routinely scheduled standardized testing plays a role in this. I find that I am often more generous in my grading/feedback compared to the teachers here, which was not something I noticed back home. During my practice teaching in Ontario, I noticed a higher emphasis was placed on providing positive feedback. This is not to say that positive feedback is not used here, but just that there seems to be a culture of using direct, constructive criticism to motivate students. 
Calum said his family has three sheep still ready "to lamb." I learned that early spring is the season in which most lambs are born.

They count birthdays from February to February for school years. I'm not sure why. In Ontario, we usually categorize school years according to birth years (i.e. all students born in 1995 would begin kindergarten the same year).

Take note, Canadian English teachers. Here are the classroom management strategies I have noticed are effective in Scotland:

1. Always give the students a timeframe. For instance, how long do they have to work on this activity? Remind them when they are getting close to the end of the time.

2. Be direct and immediate. For example, when students become too talkative, be quick to respond.

3. For lower level classes and more disruptive classes, always have tasks for them to accomplish.

4. For larger classes, have them report answers and discuss as a group, otherwise too many students will try to answer at once.

5. Have students peer edit writing activities often and early in the process. This helps to ensure that they are completing the task properly and it breaks up the lesson

6. Use a desk bell to capture their attention rather than having to use your voice.

7. Use coloured cups that mean, "I am confident in what I am doing;" "I need some help from members of my group;" and "I need some help from my teacher."

\section{Day Four}

I find I am very much enjoying teaching the year ones. So many things are new to them still (including the uniform, which they wear with much more enthusiasm than the older students) and they are so excited to learn. Today, we went over literary devices. I taught them how to properly say "hyperbole" and now they say it with a Canadian accent.

The S6 students are preparing for a school trip to Glasgow. They talk about it often. In particular, their excitement for many of them to try McDonald's for the first time.

This evening, the other Canadian student teachers and I met Mr. Smith and a group of teachers from the primary school to play Shinty. The sport seems like golf and field hockey combined. I tried a few hits during warm-ups and found it quite fun. The stick was made of wood and heavier than I expected. Once the game began, I stood on the sidelines and took pictures. The field was surrounded by grey, stone townhouses. Soon the sky grew dark, and it began to rain. The wet cold acquired my fingers and I had to stop taking photos (although I did manage to capture a lovely double rainbow). Mr. Smith showed up again at 8:00pm and encouraged me to wait in his car until the game was over. Mr. Smith's son, Rory, who is a first-year student at the secondary school, was also in the car. He said he plays rugby rather than soccer (he said "soccer" - nice boy!) and gets to miss five periods a week for training.

It is not surprising his favourite subject is 'P.E.' (physical education). 
Rory said "this is [his] first year studying French." He says he hasn't quite caught on to it yet.

More common diction overheard: jumper (sweater), Tipp-ex (correction tape or 'WiteOut'), and water closet (washroom).

\section{Day Five}

Miss Macleod was away today for an interview, so I was asked to cover registration and year-one first and fifth periods. When a teacher is away or ill, it seems common that the other teachers in the school work together to cover classes during their open periods, rather than having hired occasional teachers come in like in Windsor. I wonder if this is common in all of Scotland, or if it is unique to this area. Being asked to take this on made me feel like a real teacher more than anything.

During third and fourth period I observed year one and two keyboard/guitar class. The teacher told me that it was not the best time to be observing the year two class because they've already chosen their classes for next year and many of them did not choose music, so they are very disinterested. They worked from a music book with a variety of familiar songs such as "Summer Nights", "Auld Lang Syne", and "Hedwig's Theme." "Auld Lang Syne" is one of my favourite pieces of music (and poetry) and I was delighted to see it being taught in a Scottish classroom (it is not as familiar to students in Windsor). While the students worked independently, the teacher would come around to see how they were getting on. A couple of the advanced guitar students practiced a more difficult piece in a private room.

The year one music class had several of the boys from my English group. They were taking turns on the drums and saying "jumping jelly" to help them keep time. They struggled to hit the snare and bass drums at different beats.

Nearly every student we've met has family somewhere in Canada, mostly in the eastern provinces. We were often told, "I have an uncle in New Brunswick" or "I have cousins on Cape Breton Island." The kinship towards Canada here has been notable; more than other countries I've visited.

The headmistress commented on my "pinafore" dress today, saying that it fondly reminded her of one she had when she was a young woman.

\section{Day Six}

Today, I taught show not tell to the S2 creative writing class and Miss McLeod helped me develop learning outcomes for an activity, which she referred to as "Success Criteria." Cory said, "There's a better way to exercise inside. If you turn on the fan and play badminton at the fan."

A few of the S6 students are in the process of writing personal essays for their university applications. When the headmistress learned that my academic background was in creative writing, she assigned me to work with one of the students. Mauve's essay explored her experience witnessing a bull fight for the first time in Spain. I provided many marginal comments on her work, 
and we met together to go over the feedback. I found this one-on-one very rewarding because of the direct connection.

We also heard from one of the other Canadian student teachers that some of the students saw my colleague and me sitting on a hill the evening before, "watching the sheep" (really, it was the lambs). They were very confused by this, since sheep here were as common as cows in Ontario. While I didn't have the opportunity to talk to these students about it directly, I hoped that maybe we provided a glimpse of a different perspective. A reminder that what might be ordinary to some is extraordinary to others. At the very least, we gave them a laugh.

\section{Day Seven}

Today, I worked again with my lovely year one students. We did an editing workshop using postit notes (or 'sticky notes', as they would say) and went over how to give constructive feedback. I had them work in their table groups and counted to three each time they had to move onto the next one. It is incredible how something as simple as counting makes it much more exciting for them. Each time I counted, they would get in position as if they were preparing for a race and jump to the next table. Nicole asked if I would be here again on Thursday, so she could get a photo with me and "an autograph."

I co-taught a year one class with another Canadian student teacher on poetry, specifically haikus. We made one together as a class. We continued "show not tell", and the rain exercise from Mary was beautiful.

Before leaving the school, I paused at the top of the stairs in the main hall. Its openness provided an opportunity to gaze, one last time, at the multi-coloured art installation, the lunch tables folded neatly along the wall, the lime green chairs stacked, a few loose papers. The students were gone, and most of the teachers were in their classrooms preparing to go home. It was quiet.

In conclusion, here are ten suggestions for Canadian student teachers in Scotland:

1. When in doubt, talk about Canada (the students love it).

2. Pack light. You won't need as much as you think you will.

3. Bring a good raincoat.

4. Walk as much as you can.

5. Meet as many of the teachers as possible.

6. Offer to teach as much as you can.

7. Eat haggis and black pudding.

8. Take photos.

9. Keep a journal.

10. Read students' academic and creative work. 


\section{References}

Clarà, M., Mauri, T., Colomina, R., \& Onrubia, J. (2019). Supporting collaborative reflection in teacher education: A case study. European Journal of Teacher Education, 42(2), 175-191.

Hassaram, B., Robertson, P. M., \& Garcia, S. B. (2019). Challenges and possibilities of scaffolding critical reflection and cultural responsiveness for pre-service special educators. Journal of Teaching and Learning, 12(2), 1-22.

\section{Л几}


